\title{
The effect of propylene glycol delivery method on blood metabolites in dairy cows
}

\author{
Robert Mikuła $^{1}$, Ewa Pruszyńska-Oszmałek ${ }^{2}$, Marta Ignatowicz-Stefaniak ${ }^{1}$, \\ Paweł Antoni Kołodziejski², Paweł Maćkowiak ${ }^{2}$, Włodzimierz Nowak ${ }^{1}$ \\ Poznań University of Life Sciences, Faculty of Veterinary Medicine and Animal Science, \\ ${ }^{1}$ Department of Animal Nutrition, Poznań, Poland, \\ ${ }^{2}$ Department of Animal Physiology and Biochemistry, Poznań, Poland
}

Received May 22, 2018

Accepted January 28, 2020

\begin{abstract}
Four dairy cows in a positive energy balance were used to study the effect of propylene glycol supplementation variants on blood indices. The treatments were: without glycol, glycol mixed with the total mixed ration (TMR), glycol delivered as top dressing (TD), and glycol administered as an oral drench (OD). Oral drenching had the positive effect of higher blood insulin concentration 1.5 and $2.5 \mathrm{~h}$ after supplementation compared to the TD method $(P \leq 0.05)$. Glycol supplemented as TD had the negative effect of higher concentration of non-esterified fatty acids (NEFA) 3.5 $\mathrm{h}$ after supplementation $(P \leq 0.05)$ with a trend towards a higher mean concentration of this marker $(P \leq 0.1)$. A decreasing tendency was recorded for the NEFA concentration $1.5 \mathrm{~h}$ after glycol supplementation with TMR or OD $(P \leq 0.1)$. Glycol supplemented as OD had the positive effect of lowering the $\beta$-hydroxybutyric acid concentration 1.5 and $2.5 \mathrm{~h}$ after feeding $(P \leq 0.05)$. A downward trend in the mean $\beta$-hydroxybutyric acid level after glycol delivery as OD was also observed $(P \leq 0.1)$. Glycol supplemented as TD had the negative effect of decreasing dry matter intake of the diet $(P \leq 0.05)$. Glycol supplemented as OD had a more glucogenic effect than as part of the TMR. Due to reduction of dry matter intake and the lowest glucogenic effect, using glycol as TD is unjustified. The results confirm that the best method of propylene glycol administration is OD, which can be useful in the prevention of ketosis, however, it should be confirmed in a longterm experiment covering the transition and early lactation periods.
\end{abstract}

Ketosis prevention, glucose, insulin, non-esterified fatty acids, $\beta$-hydroxybutyric acid

Over the last years, dairy cows have undergone genetic selection which has increased milk production to a level where it is difficult to meet the nutrient requirements with the diet (Mulligan and Doherty 2008). Imbalance of energy inputs relative to energy yielding outputs is especially observed during the transition period when reduced feed intake is noted. Then, mobilisation of fatty acids from the adipose tissue increases blood non-esterified fatty acid (NEFA) concentration (Christensen et al. 1997). The NEFA may be oxidised for fuel, converted back into triglycerides and deposited as fat droplets in hepatocytes, as well as converted to ketones in the liver (Sordillo and Mavangira 2014). An increased NEFA level in dairy cows' blood during a negative energy balance is often associated with the accumulation of triglycerides in hepatocytes, thus impairing liver function and elevating ketone production. Moreover, an increased level of NEFA in blood could have a negative effect on oocyte development and reproductive performance (Walsh et al. 2007). Sordillo and Raphael (2013) claimed that a progressive increase in blood NEFA levels before calving may be considered a significant factor promoting inflammatory responses of transition cows. A higher blood NEFA concentration could be related to an increased risk of displaced abomasum (Chapinal et al. 2011), metritis and retained placenta (Ospina et al. 2010a), lower milk yield (Ospina et al. 2010b), while it may also result in a greater early-lactation culling risk (Roberts et al. 2012). Propylene glycol (PG) is a glucogenic precursor, thus its supplementation is one of the methods used in the treatment of ketosis in postparturient dairy cows. Propylene glycol is metabolised

Address for correspondence:

Robert Mikuła

Department of Animal Nutrition

Poznań University of Life Sciences

Wołyńska 33, 60-637 Poznań, Poland

Phone: +48 618487222

E-mail: robert.mikula@up.poznan.p

http://actavet.vfu.cz/ 
to propionate. It directly increases the propionate concentration in the rumen and can be converted to glucose via gluconeogenesis in the liver (Nielsen and Ingvartsen 2004). Many authors claim that propylene glycol could be effective in reducing the NEFA concentration in blood (Rizos et al. 2008; Liu et al. 2009). The decrease of blood NEFA is probably mediated by insulin, which is antilipolytic and responsive to elevated blood glucose levels (Christensen et al. 1997). Unfortunately, PG has a varied effect on dairy cows' blood indices (Nielsen and Ingvartsen 2004; Piantoni and Allen 2015). The effect of PG seems to be probably dependent on the delivery method of this glucogenic substance. In a previous study (Mikuła et al. 2008) we concluded that the lack of a positive effect of PG is probably consequential to the method of application as a top dressing (TD) supplementation. Thus, the aim of this study was to determine the glucogenic and antiketotic effect of PG supplementation methods in dairy cows.

\section{Materials and Methods}

All animal procedures were conducted in accordance with the guidelines of the Polish Council of Animal Care. The protocol for this study was approved by the Local Animal Care Committee no. 10 of the Poznań University of Life Sciences (Acceptance No. 68/2008).

Animal management, propylene glycol and experimental diet

Four Polish Holstein dairy cows in their second lactation ( $129 \pm 8$ days in milk, $35 \pm 1 \mathrm{~kg}$ of milk/d) were used in a $4 \times 4$ Latin square design. The experimental treatments were as follows: CON - without propylene glycol; TMR - $400 \mathrm{ml} / \mathrm{d}$ of PG mixed with the morning part of total mixed ration (TMR); TD - $400 \mathrm{ml} / \mathrm{d}$ of PG delivered as top dressing on the morning part of TMR; OD $-400 \mathrm{ml} / \mathrm{d}$ of PG delivered as oral drenching in the same time when TMR was delivered. The study consisted of 4 periods of 14 days each. The treatments were used during all time periods. PG (95.5\% of 1,2-propanodiol, Brentag Polska sp. z o.o., Poland) was used in the liquid form. The cows were fed individually twice a day with a TMR complete ration in accordance with the IZ PIB - INRA recommendations (Strzetelski 2009). The diet (Table 1) met the requirements for the production of $37.5 \mathrm{~kg}$ milk/d with $4 \%$ of milk fat and was balanced using the INRAtion 3.3 computer programme. The feed nutrition value was estimated by PrevAlim 3.23 on the basis of chemical analyses (AOAC 2005; Horwitz and Latimer 2005; Polish Norm PN 2009) of dry matter (AOAC 934.01), crude protein (AOAC 976.06), acid detergent fibre (PN-EN ISO 13906) and crude ash (AOAC 942.05).

\section{Sample collection and chemical analyses}

Blood samples were collected in the last 14 days of each Latin square periods from the jugular vein $0.5 \mathrm{~h}$ before and $0.5,1.5,2.5,3.5,5,7,9,11 \mathrm{~h}$ after PG administration as OD and morning feeding (CON, TMR, TD) into a tube with polystyrene separating granules covered with a clot activator. After $1 \mathrm{~h}$ the samples were rotated in a centrifuge, the serum was separated and frozen at $-20^{\circ} \mathrm{C}$ for later analysis. Serum was thawed and analysed for NEFA concentration according to Duncomb's colorimetric method (Duncombe 1964). The concentrations of glucose, triglycerides, $\beta$-hydroxybutyric acid (BHBA) and blood urea nitrogen (BUN) were assayed using a Pointe Scientific (Canton, USA) reagent kit (G7518-400, T7531-400, H7587-58, B7550-400). Serum hormone concentrations were analysed using radioimmunoassay (RIA) methods: insulin (PI-12K, Millipore Corporation, Burlington, USA), insulin-like growth factor I (IGF-I; DSL-2800, Diagnostic Systems Lab., Webster, USA), leptin (XL-85K, Millipore Corporation, Burlington, USA), ghrelin (GHRT-89HK, Linco Research, St. Charles, USA), thyroxine, and triiodothyronine (OCPG07-T4, OCPE07-T3, CISBIO International, Codolet, France). Individual voluntary dry matter intake was measured and recorded daily before the morning and afternoon feeding.

\section{Statistical analyses}

The obtained results were processed statistically using the SAS 9.1 statistical computer program package. One way analysis of variance was carried out using the GLM procedure and Duncan test. The model contained the effect of treatment (CON, TMR, TD, OD), the effect of the cow and the effect of the period and sampling error. Significance was declared at $P \leq 0.05$ and, in turn, trends were considered when $0.05<P \leq 0.1$.

\section{Results}

The method of PG delivery had no significant effect on the blood glucose concentration $(P>0.05)$ (Fig. 1). Oral drenching with PG had a positive effect leading to the highest blood insulin concentration at 1.5 and $2.5 \mathrm{~h}$ after this substance administration compared 


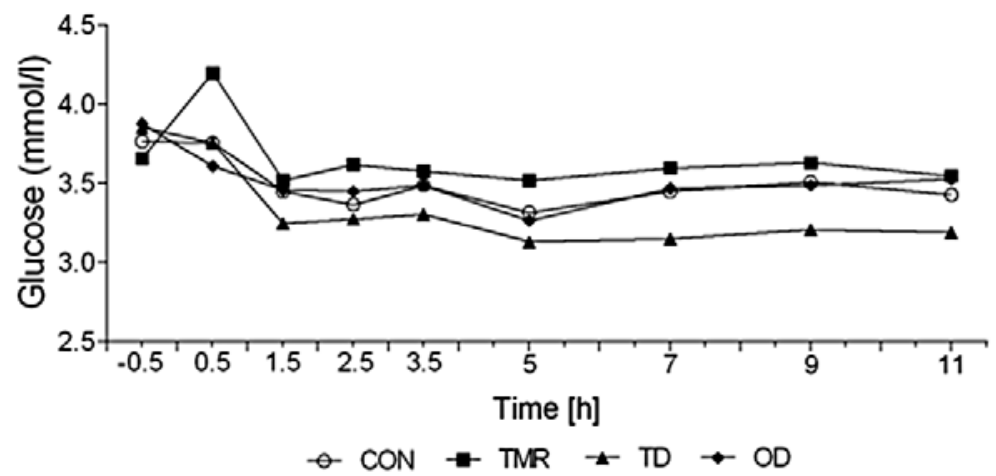

Fig. 1. Effect of propylene glycol delivery method on the blood glucose concentration.

CON - without propylene glycol, TMR - $400 \mathrm{ml} / \mathrm{d}$ of propylene glycol mixed with total mixed ration; TD - $400 \mathrm{ml} / \mathrm{d}$ of propylene glycol delivered as top dressing, OD $-400 \mathrm{ml} / \mathrm{d}$ of propylene glycol delivered as oral drenching

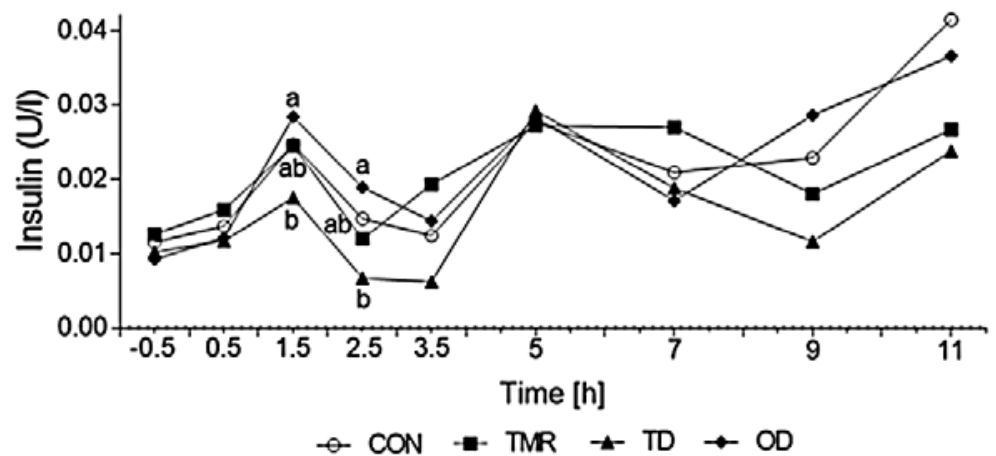

Fig. 2. Effect of propylene glycol delivery method on insulin concentration.

CON - without propylene glycol, TMR - $400 \mathrm{ml} / \mathrm{d}$ of propylene glycol mixed with total mixed ration; TD $-400 \mathrm{ml} / \mathrm{d}$ of propylene glycol delivered as top dressing, OD $-400 \mathrm{ml} / \mathrm{d}$ of propylene glycol delivered as oral drenching

a,b Significant differences between groups are indicated by different superscripts $(P \leq 0.05)$.

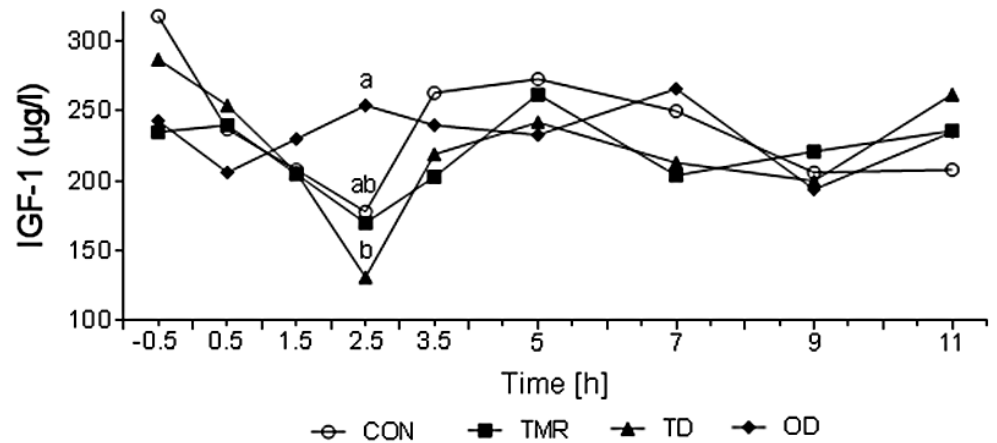

Fig. 3. Effect of propylene glycol delivery method on insulin like growth factor - I (IGF - 1) concentration. CON - without propylene glycol, TMR - $400 \mathrm{ml} / \mathrm{d}$ of propylene glycol mixed with total mixed ration; TD $-400 \mathrm{ml} / \mathrm{d}$ of propylene glycol delivered as top dressing, OD $-400 \mathrm{ml} / \mathrm{d}$ of propylene glycol delivered as oral drenching

a,b Significant differences between groups are indicated by different superscripts $(P \leq 0.05)$. 


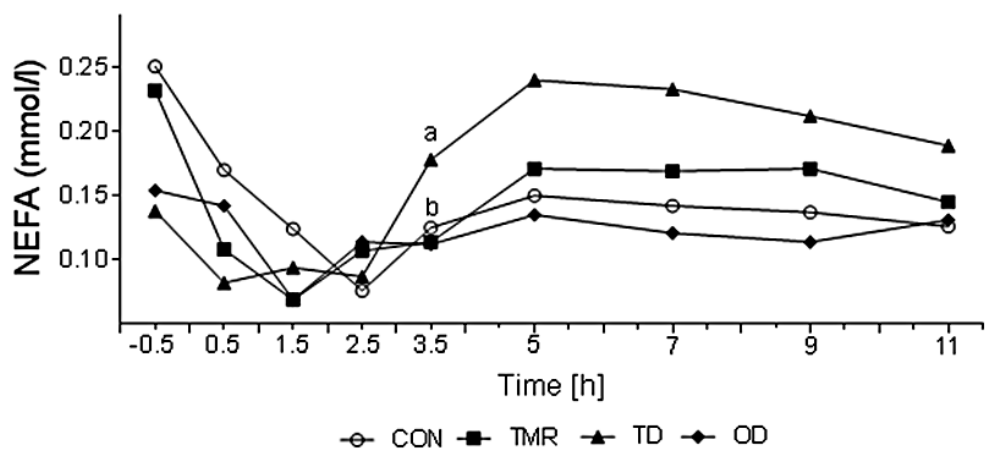

Fig. 4. Effect of propylene glycol delivery method on nonesterified fatty acids (NEFA) concentration.

CON - without propylene glycol, TMR - $400 \mathrm{ml} / \mathrm{d}$ of propylene glycol mixed with total mixed ration; TD - $400 \mathrm{ml} / \mathrm{d}$ of propylene glycol delivered as top dressing, OD - $400 \mathrm{ml} / \mathrm{d}$ of propylene glycol delivered as oral drenching

a,b Significant differences between groups are indicated by different superscripts $(P \leq 0.05)$.

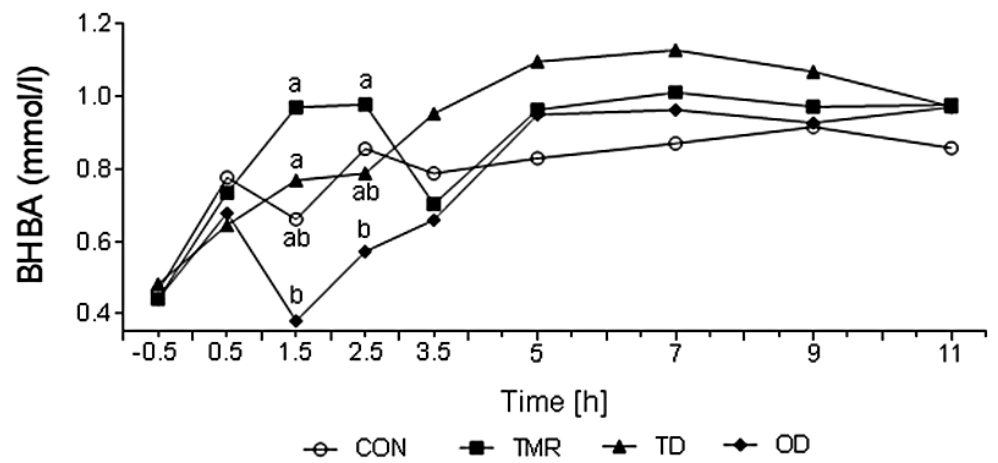

Fig. 5. Effect of propylene glycol delivery method on $\beta$-hydroxybutyric acid (BHBA) concentration.

CON - without propylene glycol, TMR - $400 \mathrm{ml} / \mathrm{d}$ of propylene glycol mixed with total mixed ration; TD - $400 \mathrm{ml} / \mathrm{d}$ of propylene glycol delivered as top dressing, OD - $400 \mathrm{ml} / \mathrm{d}$ of propylene glycol delivered as oral drenching

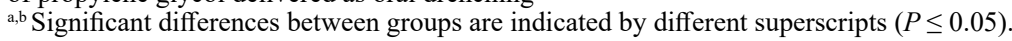

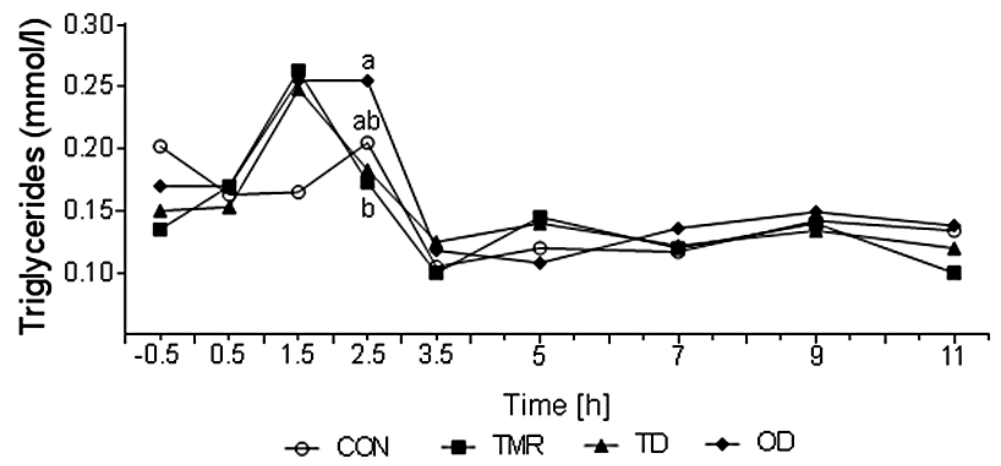

Fig. 6. Effect of propylene glycol delivery method on triglyceride concentration.

CON - without propylene glycol, TMR - $400 \mathrm{ml} / \mathrm{d}$ of propylene glycol mixed with total mixed ration; TD - $400 \mathrm{ml} / \mathrm{d}$ of propylene glycol delivered as top dressing, OD - $400 \mathrm{ml} / \mathrm{d}$ of propylene glycol delivered as oral drenching

${ }^{\mathrm{a}, \mathrm{b}}$ Significant differences between groups are indicated by different superscripts $(P \leq 0.05)$. 


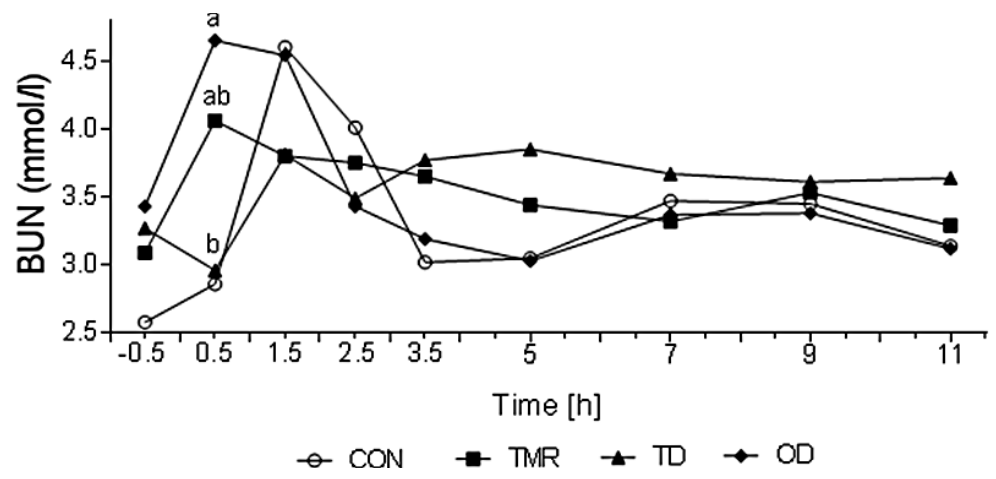

Fig. 7. Effect of propylene glycol delivery method on blood urea nitrogen (BUN) concentration.

CON - without propylene glycol, TMR - $400 \mathrm{ml} / \mathrm{d}$ of propylene glycol mixed with total mixed ration; TD - $400 \mathrm{ml} / \mathrm{d}$ of propylene glycol delivered as top dressing, OD - $400 \mathrm{ml} / \mathrm{d}$ of propylene glycol delivered as oral drenching

a,b Significant differences between groups are indicated by different superscripts $(P \leq 0.05)$.

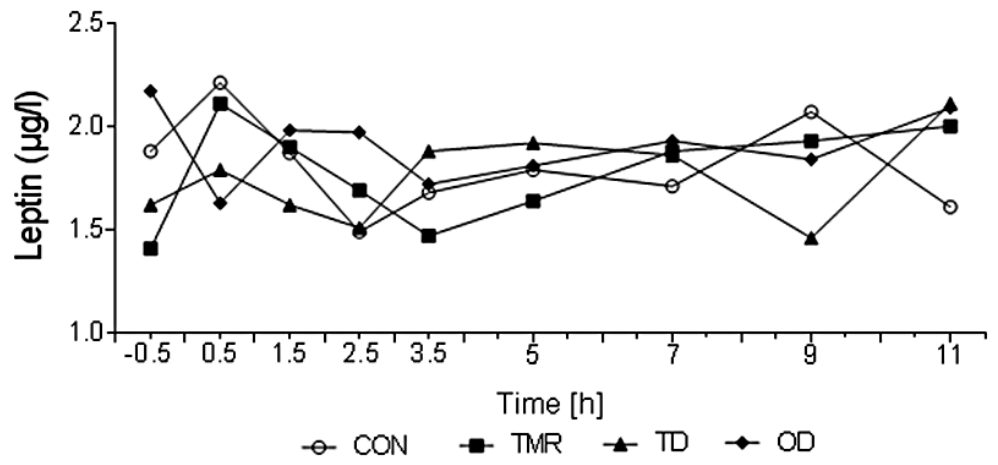

Fig. 8. Effect of propylene glycol delivery method on leptin concentration.

CON - without propylene glycol, TMR - $400 \mathrm{ml} / \mathrm{d}$ of propylene glycol mixed with total mixed ration; TD - $400 \mathrm{ml} / \mathrm{d}$ of propylene glycol delivered as top dressing, OD - $400 \mathrm{ml} / \mathrm{d}$ of propylene glycol delivered as oral drenching

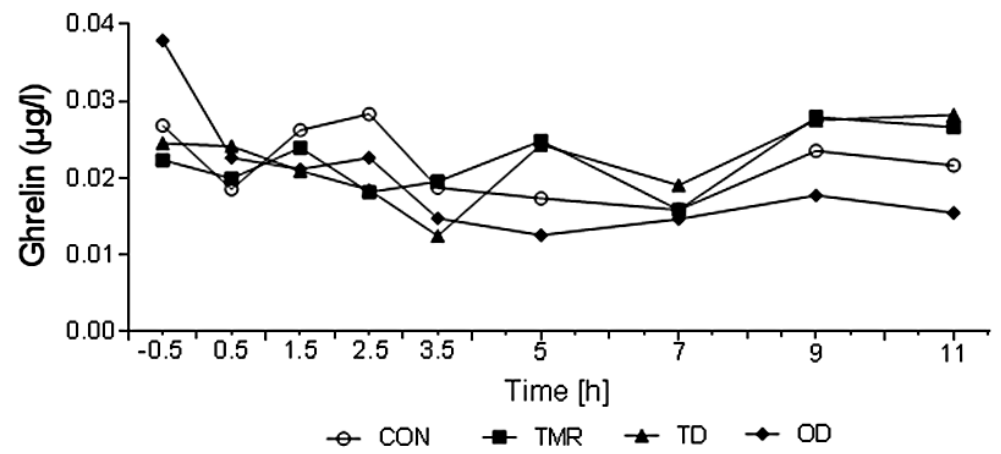

Fig. 9. Effect of propylene glycol delivery method on ghrelin concentration.

CON - without propylene glycol, TMR - $400 \mathrm{ml} / \mathrm{d}$ of propylene glycol mixed with total mixed ration; TD $-400 \mathrm{ml} / \mathrm{d}$ of propylene glycol delivered as top dressing, OD $-400 \mathrm{ml} / \mathrm{d}$ of propylene glycol delivered as oral drenching 


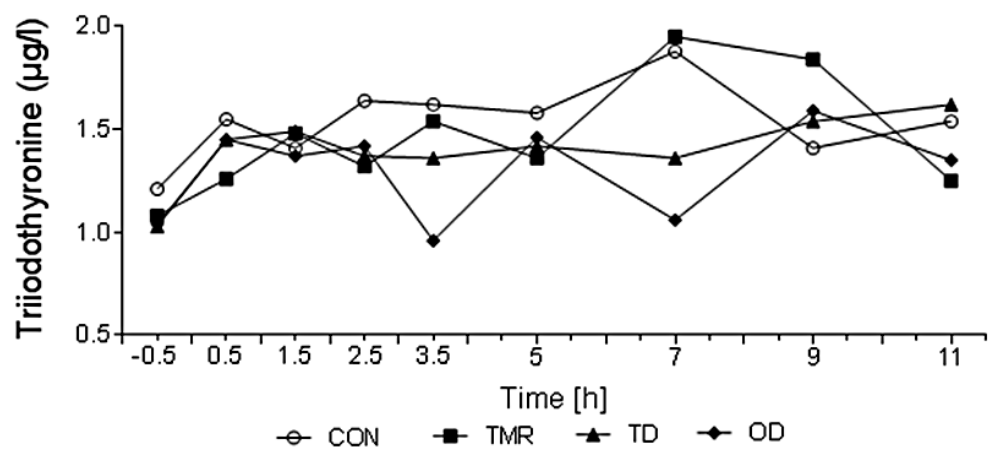

Fig. 10. Effect of propylene glycol delivery method on triiodothyronine concentration.

CON - without propylene glycol, TMR - $400 \mathrm{ml} / \mathrm{d}$ of propylene glycol mixed with total mixed ration; TD - $400 \mathrm{ml} / \mathrm{d}$ of propylene glycol delivered as top dressing, OD - 400 $\mathrm{ml} / \mathrm{d}$ of propylene glycol delivered as oral drenching

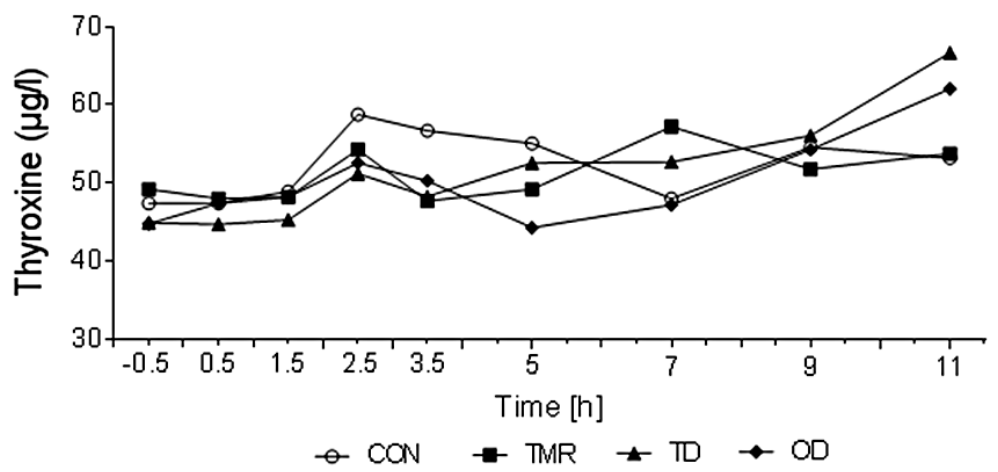

Fig. 11. Effect of propylene glycol delivery method on thyroxine concentration.

CON - without propylene glycol, TMR - $400 \mathrm{ml} / \mathrm{d}$ of propylene glycol mixed with total mixed ration; TD - $400 \mathrm{ml} / \mathrm{d}$ of propylene glycol delivered as top dressing, OD - 400 $\mathrm{ml} / \mathrm{d}$ of propylene glycol delivered as oral drenching

to the TD method $(P \leq 0.05)$ (Fig. 2). A negative trend towards a lower mean blood insulin concentration after PG delivery as TD was observed when compared with other PG administration methods ( $P \leq 0.1$; data not shown). A rise of insulin concentration at $1.5,5$, and $11 \mathrm{~h}$ after feeding was recorded (Fig. 2). Around $150 \mathrm{~min}$ after PG OD the highest concentration of IGF-I was observed when compared with TD administration $(P \leq 0.05)$ (Fig. 3). The same method of PG application (TD) resulted in higher NEFA concentrations $3.5 \mathrm{~h}$ after feeding compared with other cows $(P \leq 0.05)$ (Fig. 4). A negative trend of higher mean NEFA concentrations after PG administration as TD was observed $(P \leq 0.1$; data not shown). The trend toward the lowest NEFA concentration was recorded at $1.5 \mathrm{~h}$ (TMR, OD) $(P \leq 0.1)$ (Fig. 4). Administration of $\mathrm{PG}$ as OD had a positive effect resulting in the lowest BHBA concentration at 1.5 and $2.5 \mathrm{~h}$ after feeding, which was significantly relevant between TMR and TD $(1.5 \mathrm{~h})$ and TMR $(2.5 \mathrm{~h})(P \leq 0.05)$ (Fig. 5). A positive effect on the lowest mean BHBA blood concentration after OD with PG compared with TD and TMR methods was noted $(P \leq 0.1$; data not shown). Administration of PG as OD increased blood triglyceride concentrations at $2.5 \mathrm{~h}$ after supplementation in comparison to the TMR and TD methods $(P \leq 0.05)$. The highest triglyceride level was recorded in cows' blood with PG supplementation (TMR, TD, OD methods) at $1.5 \mathrm{~h}$ after feeding 
Table 1. Ingredients and nutrient composition of experimental TMR diet.

\begin{tabular}{lc}
\hline Ingredients & \% of DM \\
\hline Maize silage & 26.9 \\
Alfalfa silage & 12.1 \\
Sugar beet pulp silage & 11.2 \\
Brewer's grain silage & 8.1 \\
Soybean meal & 1.8 \\
Rapeseed meal & 7.9 \\
Triticale grain & 17.6 \\
Barley grain & 7.7 \\
Wheat straw & 3.6 \\
Minerals and vitamins & 3.1 \\
Nutrient composition & \\
UFL & 21.6 \\
PDIN (g) & 2225 \\
PDIE (g) & 2248 \\
Ca (g) & 203 \\
P (g) & 89 \\
LFU & 17.9 \\
VDMI (kg) & 24.7 \\
\hline
\end{tabular}

TMR - total mixed ration, DM - dry matter, UFL - feed unit for lactation (1700 kcal NEL), PDIN - dietary protein undegraded in the rumen, but truly digestible in the small intestine and microbial protein which could be synthesized in the rumen from degraded dietary nitrogen, when energy and other nutrients are not limiting, PDIE dietary protein undegraded in the rumen, but truly digestible in the small intestine and microbial protein which could be synthesized in the rumen from the energy available in the rumen, when degraded nitrogen and other nutrients are not limiting, LFU - fill unit for lactating dairy cows, VDMI - voluntary dry matter intake
$(P \leq 0.1)$ (Fig. 6). At 30 min after PG OD, a significant increase in the BUN concentration was observed in comparison to TD application and diet without PG $(P \leq 0.05$; Fig. 7$)$.

The method of PG delivery had no effect on leptin (Fig. 8), ghrelin (Fig. 9), triiodothyronine (T3, Fig. 10), and thyroxine (T4, Fig. 11) levels in blood. Propylene glycol delivered as TD reduced $(P \leq 0.05)$ voluntary dry matter intake by $2.6 \mathrm{~kg}$ in comparison to the other application methods, where the average dry mater intake was approximately $23.3 \mathrm{~kg}$ (data not shown).

\section{Discussion}

Available literature sources provide inconsistent information concerning the positive, glucogenic effect of PG feed of dairy cattle. Moreover, there are more and more reports which propose the best method of feed additive supplementation to maintain optimal animal welfare. In the previous study

(Mikuła et al. 2008) no significant positive effect of PG was observed on the majority of the analysed biochemical markers of blood. It may be assumed that the weaker than anticipated glucogenic effect of PG resulted from the TD treatment method (Kristensen and R a u n 2007). Therefore, in this study we present the effect of PG application methods on changes in the dynamics of biochemical blood markers in dairy cattle.

It may be assumed that PG as a glucogenic substance might increase the blood glucose concentration. We statistically proved that none of the PG application methods (as a TMR component, TD or OD) resulted in increased blood glucose concentration. Similar results were obtained by Christensen et al. (1997) when comparing similar methods of PG application and blood taken at 0,30,60,90,180 and 330 min after PG was delivered, and by Chung et al. (2009a) who analysed two variants of the PG application: as a TMR component and TD. In the latter study, blood glucose analyses covered the period from 0 to 240 min with 20-min intervals and also 480 and 720 min after PG was administered. No effect of PG administration via a TMR component and single esophageal feeding or ruminal feeding (through a rumen cannula) was observed also by Chung et al. (2009b). In their study, blood samples were collected from 0 to 240 min with 10- or 20-min intervals after treatment administration and that observation was consistent with our results. Different results were obtained by Grummer et al. (1994), who observed an increased glucose concentration in the blood of heifers from 0 to $360 \mathrm{~min}$ after the esophageal 
feeding of 296, 592 and 887 grams of PG. Adamski et al. (2011) reported an increased glucose concentration in the blood of cows before the morning feeding after PG treatment in the form of a TMR component compared to the control group. The obtained data confirmed that glucose concentration in the blood is not an effective marker of energy balance. Also, Chung et al. (2009b) confirmed our observation; they argued that there are only slight changes in glucose concentration, which may result from the high effectiveness of the system responsible for the regulation of the level of this marker in the blood. A similar opinion is proposed by LeBlanc (2010), who argued that the use of glucose as a marker of metabolic status is questionable because of homeostatic glucose regulation. Kristensen and Raun (2007) suggested that increased concentration of PG and its ruminal fermentation product, propanol, in the blood influence insulin resistance of peripheral tissues, increase insulin and glucose levels and have hypoketonaemic effects.

Although no significant effect on glucose concentration was confirmed, OD with PG increased the insulin level after 1.5 and $2.5 \mathrm{~h}$ and IGF-I level $2.5 \mathrm{~h}$ after the application of the supplement compared to the TD application.

These results confirm the highest glucogenic effectiveness of OD with PG. It may be assumed that an increased synthesis of propionic acid in the rumen after a single esophageal application of PG will stimulate insulin release from the pancreas (Kristensen and Raun 2007; Chung et al. 2009b). In addition, Christensen et al. (1997) reported a positive glucogenic effect of esophageal $\mathrm{PG}$ application on increased insulin concentration compared to PG application in the form of a TMR component. According to Chung et al. (2009b), PG esophageal and ruminal application increased insulin concentration in the blood compared to the TMR component method. The same authors (Chung et al. 2009a) reported an increased insulin concentration at 1.5 and $2.5 \mathrm{~h}$ after a single PG application compared to the control feeding without the supplement addition. Different results were obtained by Chibisa et al. (2008), who did not confirm the effect of PG added to the TMR on insulin concentration in the blood. It is known that insulin is the key hormone, facilitating glucose passage through cell membranes, which has an effect on the endocrine regulation of glucose concentration in the blood. Vernon et al. (2005) argued that insulin is involved in the lipid metabolism of cows in the perinatal period, reducing blood NEFA and BHBA concentrations. The observed changes in the metabolite profile in our study partially confirm this hypothesis. Zammit (1999) reported a decrease in lipolysis in cows after esophageal administration of PG and lower NEFA and BHBA concentrations, which indicates reduced hepatic ketogenesis. Kristensen and Raun (2007) obtained similar results after ruminal application of PG. On the contrary, Christensen et al. (1997) found that OD with $\mathrm{PG}$ resulted in a reduced NEFA concentration, while significant changes in blood BHBA levels were not confirmed. Similarly to our results, Chibisa et al. (2008) showed that PG supplementation as TD did not change NEFA and BHBA concentrations in the blood compared with the control feeding without supplementation. Oral drenching with PG reduced the concentration of triglycerides in the blood after $2.5 \mathrm{~h}$, in comparison with other forms of supplementation and the control group. According to Djokovic et al. (2007), increased lipogenesis and ketogenesis in the liver resulted in decreased triglyceride concentrations in the blood. Thus, the obtained results regarding triglyceride concentrations at $2.5 \mathrm{~h}$ after OD with $\mathrm{PG}$ confirm the glucogenic efficiency of this form of supplementation. It may be assumed that PG has a slight effect on the modification of fermentation in the rumen, because only esophageal supplementation (after $0.5 \mathrm{~h}$ ) resulted in an increased BUN concentration in the blood. Similarly, Chung et al. (2009b) reported that a single PG dose did not reduce nitrogen accessibility to rumen microorganisms by analysing ammonia concentration in the rumen. Miyoshi et al. (2001) noticed a tendency to increased BUN concentration after esophageal PG application. Chibisa et al. (2008) did not statistically confirm the influence of PG on BUN concentration. 
The effect of PG on hormone concentrations in tissues or leptin and ghrelin levels were not confirmed. Morris on et al. (2001) proved that leptin released by the adipocytes inhibits forage uptake, while Block et al. (2003) presented a negative correlation between leptin concentration and non-esterified fatty acid level. Probably the positive energy balance of the cows included in the study caused a lack of the endocrine response in the adipocytes (Liefers et al. 2003). The effect of the PG administration method on the ghrelin level, which according to Hay a shida et al. (2001) is released by the abomasum mucosa, was not statistically confirmed. Wertz-Lutz et al. (2006) suggested that ghrelin stimulates forage uptake, whereas Takahashi et al. (2006) argued that this tissue hormone causes increased insulin secretion. Bradford and Allen (2008) also confirmed increased ghrelin secretion in the early lactation at the negative energy balance.

Regardless of the PG administration method, PG had no effect on the T3 and T4 concentrations, which may be partially confirmed by a high metabolic activity of the liver (Stojić et al. 2001). Šamanc et al. (2010) observed a gradual decrease in T3 and T4 concentrations from 30 days before calving to 12 days of lactation.

It was confirmed that PG supplemented as TD had a negative effect by decreasing the average forage dry matter intake by $2.6 \mathrm{~kg}$ compared to the other methods of supplementation and the control group. The bitter taste of PG was the probable cause of the reduced dry matter intake.

In conclusion, $\mathrm{OD}$ with $\mathrm{PG}$ resulted in the highest glucogenic effect. A positive statistical confirmation of the biochemical blood markers, such as increased insulin and IGF-I concentrations and decreased concentrations of NEFA and BHBA was observed after 2.5 and $3.5 \mathrm{~h}$. This observation should be taken into consideration for the optimisation of blood sampling time points during analyses. A possible explanation of the reduced effect of PG on concentrations of tissue hormones may be connected with a positive energy balance of the cows used in the study.

The results of this study confirm that the best method of administering propylene glycol is by OD. This method can be useful in the prevention of ketosis in dairy cows. Long term experiment covering the transition and early lactation periods is needed to verify the usefulness of the findings in practice.

\section{Acknowledgements}

The study was supported by the Polish State Committee for Scientific Research, Grant No. N N311 310736. The authors thank the Polish State Committee for Scientific Research for financial support. The authors would like to thank Janusz Kędziora and the Wilkowice farm staff for the care, management, and feeding of the cows.

\section{References}

Adamski M, Kupczyński R, Chladek G, Falta D 2011: Influence of propylene glycol and glycerin in Simmental cows in periparturient period on milk yield and metabolic changes. Arch Tierzucht 54: 238-248

Block SS, Smith JM, Ehrhardt RA, Diaz MC, Rhoads RP, Van Amburgh ME, Boisclair YR 2003: Nutritional and developmental regulation of plasma leptin in dairy cattle. J Dairy Sci 86: 3206-3214

Bradford BJ, Allen MS 2008: Negative energy balance increases periprandial ghrelin and growth hormone concentrations in lactating dairy cows. Domest Anim Endocrin 34: 196-203

Chapinal N, Carson M, Duffield TF, Capel M, Godden S, Overton M, Santos JEP, LeBlanc SJ 2011: The association of serum metabolites with clinical disease during the transition period. J Dairy Sci 94: 4897-4903

Chibisa GE, Gozho GN, Van Kessel AG, Olkowski AA, Mutsvangwa T 2008: Effects of peripartum propylene glycol supplementation on nitrogen metabolism, body composition, and gene expression for the major protein degradation pathways in skeletal muscle in dairy cows. J Dairy Sci 91: 3512-3527

Christensen JO, Grummer RR, Rasmussen FE, Bertics SJ 1997: Effect of method of delivery of propylene glycol on plasma metabolites of feed-restricted cattle. J Dairy Sci 80: 563-568

Chung YH, Brown NE, Martinez CM, Cassidy TW, Varga GA 2009a: Effects of rumen-protected choline and dry propylene glycol on feed intake and blood parameters for Holstein dairy cows in early lactation. J Dairy Sci 92: $2729-2736$

Chung YH, Martinez CM, Brown NE, Cassidy TW, Varga GA 2009b: Ruminal and blood responses to propylene glycol during frequent feeding. J Dairy Sci 92: 4555-4564 
Djoković R, Šamanc H, Jovanović M, Nikolić Z 2007: Blood concentrations of thyroid hormones and lipids and content of lipids in the liver in dairy cows in transitional period. Acta Vet Brno 76: 525-532

Duncombe WG 1964: The colorimetric micro-determination of non-esterified fatty acids in plasma. Clin Chim Acta 9: $122-125$

Grummer RR, Winkler JC, Bertics SJ, Studer VA 1994: Effect of propylene glycol dosage during feed restriction on metabolites in blood of prepartum Holstein heifers. J Dairy Sci 77: 3618-3623

Hayashida T, Murakami K, Mogi K, Nishihara M, Nakazato M, Mondal MS, Horii Y, Kojima M, Kangawa K, Murakami N 2001: Ghrelin in domestic animals: distribution in stomach and its possible role. Domest Anim Endocrin 21: 17-24

Horwitz W, Latimer G 2005: Official Methods of Analysis of the Association of Official Analytical Chemists. $18^{\text {th }}$ edn. AOAC International, Gaithersburg, Maryland, USA

Kristensen NB, Raun BML 2007: Ruminal and intermediary metabolism of propylene glycol in lactating Holstein cows. J Dairy Sci 90: 4707-4717

LeBlanc SJ 2010: Monitoring metabolic health of dairy cattle in the transition period. J Reprod Develop 56: S29-S35

Liefers SC, Veerkamp RF, te Pas MFW, Delavaud C, Chilliard Y, van der Lende T 2003: Leptin concentrations in relation to energy balance, milk yield, intake, live weight and estrus in dairy cows. J Dairy Sci 86: 799-807

Liu Q, Wang C, Yang WZ, Zhang WW, Yang XM, He DC, Dong KH, Huang YX 2009: Effects of feeding propylene glycol on dry matter intake, lactation performance, energy balance and blood metabolites in early lactation dairy cows. Animal 3: 1420-1427

Miyoshi S, Pate JL, Palmquist DL 2001: Effects of propylene glycol drenching on energy balance, plasma glucose, plasma insulin, ovarian function and conception in dairy cows. Anim Reprod Sci 68: 29-43

Mikuła R, Nowak W, Jaśkowski JM, Maćkowiak P, Pruszyńska E, Włodarek J 2008: Effects of propylene glycol supplementation on blood biochemical parameters in dairy cows. B Vet I Pulawy 52: 461-466

Morrison CD, Daniel JA, Holmberg BJ, Djiane J, Raver N, Gertler A, Keisler DH 2001: Central infusion of leptin into well-fed and undernourished ewe lambs: effects of feed intake and serum concentration of growth hormone and luteinizing hormone. J Endocrinol 168: 317-324

Mulligan FJ, Doherty ML 2008: Production diseases of the transition cow. Vet J 176: 3-9

Nielsen NI, Ingvartsen KL 2004: Propylene glycol for dairy cows: A review of the metabolism of propylene glycol and its effects on physiological parameters, feed intake, milk production and risk of ketosis. Anim Feed Sci Tech 115: 191-213

Ospina PA, Nydam DV, Stokol T, Overton TR 2010a: Evaluation of non-esterified fatty acids and $\beta$-hydroxybutyrate in transition dairy cattle in the northeastern United States: Critical thresholds for prediction of clinical diseases. J Dairy Sci 93: 546-554

Ospina PA, Nydam DV, Stokol T, Overton TR 2010b: Associations of elevated non-esterified fatty acids and $\beta$-hydroxybutryate concentrations with early lactation reproductive performance and milk production in transition dairy cattle in the northeastern United States. J Dairy Sci 93: 1596-1603

Piantoni P, Allen MS 2015: Evaluation of propylene glycol and glycerol infusions as treatments for ketosis in dairy cows. J Dairy Sci 98: 5429-5439

Polish Norm PN EN 13906 2009: Animal feeding stuffs - Determination of acid detergent fibre (ADF) and acid detergent lignin (ADL) contents.

Rizos D, Kenny DA, Griffin W, Quinn KM, Duffy P, Mulligan FJ, Roche JF, Boland MP, Lonergan P 2008: The effect of feeding propylene glycol to dairy cows during the early postpartum period on follicular dynamics and on metabolic parameters related to fertility. Theriogenology 69: 688-699

Roberts T, Chapinal N, Leblanc SJ, Kelton DF, Dubuc J, Duffield TF 2012: Metabolic parameters in transition cows as indicators for early-lactation culling risk. J Dairy Sci 95: 3057-3063

Šamanc H, Stojić V, Kirovski D, Jovanović M, Cernescu H, Vujanac I 2010: Thyroid hormones concentrations during the mid-dry period: an early indicator of fatty liver in Holstein Friesian dairy cows. J Thyroid Res 2010: 897602

Sordillo LM, Mavangira V 2014: The nexus between nutrient metabolism, oxidative stress and inflammation in transition cows. Anim Prod Sci 54: 1204-1214

Sordillo LM, Raphael W 2013: Significance of metabolic stress, lipid mobilisation and inflammation on transition cow disorders. Vet Clin N Am-Food A 29: 267-278

Stojić V, Gvozdić D, Kirovski D, Nikolić JA, Huszenicza G, Šamanc H, Ivanov I 2001: Serum thyroxine and triiodothyronine concentrations prior to and after delivery in primiparous Holstein cows. Acta Vet-Beograd 51: 3-8

Strzetelski 2009: IZ PIB-INRA Normy żywienia przeżuwaczy [IZ PIB-INRA Nutrient requirement for ruminants]. Kraków, Poland: National research Institute of Animal Production

Takahashi H, Kurose Y, Kobayashi S, Sugino T, Kojima M, Kangawa K, Hasegawa Y, Terashima Y 2006: Ghrelin enhances glucose-induced insulin secretion in scheduled meal-fed sheep. J Endocrinol 189: 67-75

Walsh RB, Walton JS, Kelton DF, LeBlanc SJ, Leslie KE, Duffield TF 2007: The effect of subclinical ketosis in early lactation on reproductive performance of postpartum dairy cows. J Dairy Sci 90: 2788-2796

Wertz-Lutz AE, Knight TJ, Pritchard RH, Daniel JA, Clapper JA, Smart AJ, Trenkle A, Beitz DC 2006: Circulating ghrelin concentrations fluctuate relative to nutritional status and influence feeding behavior in cattle. J Anim Sci 84: 3285-3300 
Vernon RG 2005: Lipid metabolism during lactation: a review of adipose tissue-liver interactions and the development of fatty liver. J Dairy Res 72: 460-469

Zammit VA 1999: Ketogenesis in the liver of ruminants - Adaptations to a challenge. J Agr Sci 115: 155-162 